\title{
The undergraduate students' beliefs about English language learning; a survey study in Madurese context
}

\author{
Fithriyah Rahmawati \\ Institut Agama Islam Negeri (IAIN) Madura
}

Received:

23-06-2020

Final revision:

23-06-2020

Published:

20-08-2020

Corresponding

author:

Fithriyah Rahmawati

fithriyahrahmawati90@gm ail.com

\begin{abstract}
The discussion in line with students' beliefs about language learning is still popular nowadays since it is believed that the student's beliefs may influence the language learning process, such as motivation, learning style, and strategies, etc. which later ultimately affected the success of language learning. This study was conducted to investigate how students of the English program at IAIN Madura (State Islamic Institute of Madura), Indonesia, express their beliefs about English language learning. This study was implemented in terms of survey study in which the data was primarily gathered by administering the questionnaire entitled Beliefs About Language learning Inventory (BALLI) of Horwitz's (1987). The questionnaires were administered to students of English teaching and learning program through Google form. About 144 undergraduate students in the first year have participated in this study. The finding revealed the students' beliefs in terms of percentage of agreements in all area of BALLI, namely language aptitude, the strategy of learning and communication, the nature of learning language, motivation and expectation in learning, and the difficulty faced by students.
\end{abstract}

Keywords: Belief, English as Foreign Language, English language learning, fresh undergraduate students

\section{Introduction}

It is generally believed that there are many factors significantly influencing the success of language learning and acquisition. It can be viewed from the intrinsic and extrinsic factors of a learner. Moreover, biological, psychological, and social factors are also noted in this case. One factor that is still popular in the discussion of language learning is about students' beliefs which may vary from one to another. This condition becomes possible concern among language practitioners.

Despite its popularity in English Language Teaching, there is no fixed operational definition of the belief itself. Even, the pioneer of research about belief, Elaine Horwitz, used term preconceptions, preconceived ideas, and preconceived notion in her article instead of applying term 'belief' (Abdi \& Asadi, 2015). Pajares (1992) cited in Abdi \& Asadi (2015) defined belief which later is considered of the reference of the belief as "attitude, values, judgements, axioms, opinions, ideology, perceptions, conceptions conceptual systems, preconceptions, dispositions, implicit theories, ..... social strategy". Another definition was proposed by Richardson (1996) said that belief is psychologically understanding, premises, or proposition about the world that seems to be true. Belief, in detail, according to Horwitz, is divided into five (5) major aspects; namely language aptitude, the difficulty in language learning, the nature of language, communication strategies, and motivation. Initially, Horwitz proposed four aspects of BALLI which added with one aspect, namely motivation and expectation as well as modifying the aspect of communication strategies (Kunt, 1996).

Aptitude deals with specific talent in language learning. According to Carrol in Saville - Troike (2012), there are four components are controlling this talent, namely coding ability of phonemic, the ability of inductive language learning, grammatical awareness, and the capacity of associative memory.

It could not be rejected that acquiring a new language (foreign languages) may take time and great effort. However, the role of motivation 
can not be neglected. It probably become the second strongest predictor after aptitude in language learning enhancement. Language learners possibly have a various motivation that enable them in language learning engagement. A student may has a desire to contact people overseas and knowing their culture as well and maybe in an attempt to pursue an educational experience in the country of the target language. In brief, motivation covers several components includes a significant goal, desire to reach the goal, feeling of learning second/ foreign language is suitable with the goals, belief of the failure and success in language learning and the value of rewards (Oxford and Ehrman in SavilleTroie 2012)

The aspect of difficulty in language learning much deals with how students perceive the target language, as well as the language skills are either easy or not. As much as beliefs of language learning concerned, the nature of language learning perception is also noticeable. Indeed, it allows students to have any perceptions of language learning should be done. Most importantly, the last aspect of students' belief in language learning is communication strategies. It deals with the students' personality which determines their strategy in learning and communication during language acquisition.

Hortwitz cited in Abdi (2015) claimed that understanding the student's belief is more influential than understanding the approach of learning language and determining classroom tasks and instruction. Further, beliefs can be viewed as "predisposition to action" (Rokeach, 1968 cited in Nikitina \& Furuoka, 2006). There is no doubt that the belief of the students is related to their behavior in the learning process. Indeed, educational psychology supports this reality that learners' beliefs are identified as a factor in determining their learning behavior and attitude (Nikitina \& Furuoka, 2006). Most importantly, it becomes a potential key to make the language learning process is successful which leads to students' positive development. Regarding this notion, evidence suggested that beliefs of learners in English language learning bring about the potential effects of their learning development and experiences (Zare-ee, 2010;); (Peralta Castro \& Andrade-Arechiga, 2017).

The topic of students' belief has become a great discussion among the teachers/ lecturers, students themselves and educational or language scholars, and the curriculum designers, as well as the institution concerning language learning. It is also considered in the context of Madurese undergraduate students of State Islamic Institute of Madura (IAIN Madura), Indonesia. The majority of students are Madurese who come from many areas in Madura including the students of the English teaching and learning program in Tarbiyah Faculty. Regarding this, the students who have been enrolled in the English Language study program are shaped to be an English teacher, language practitioner, translator, and other jobs related to English. The majority of students are Madurese who consider English as a foreign language. As Indonesian students, it has been noticed that they have formally obtained a general English subject when they were senior high school students. Madurese students with all various characteristics attached to them become the most concern to be explored about their belie in language learning. Therefore, it is worthy to identify their beliefs in English language learning which later beneficial in determining the strategy, style, learning process, and so on.

An enormous of studies have been carried out regarding exploring students' belief in language learning, especially in the English learning context. Those studies brought findings that may vary from other findings. The vary of the findings depends on the method and the design of the research. The pioneer of research about beliefs was conducted by Horwitz among students in the University of Texas, the beliefs about English learning, she also identified the beliefs of students in the Spanish, French, and Germany context. Moreover, the teachers' beliefs is also investigated ((Kunt, 1996). A study by Abdolahzadeh and Nia (2014) was conducted in terms of examining the relationship between language learning beliefs and language mastery. The result indicated that the respondents endorsed strong beliefs in the aspect of motivation, expectation, as well as the language aptitude of English. Moreover, the finding of the study also showed the positive correlation between students' language proficiency and their belief in English learning. Moreover, a study by Boakye (2011) assessed the students' beliefs in all categories and found that their beliefs may negatively influence their learning strategy. Meanwhile, a study by Ariogul (2009) provided a comparison between three language learners (English, German, and French) in Turki about their belief about language learning. There is no doubt that it could effect their development. In the Indonesian context, a study conducted by Amrullah (2018) delineated a survey result about students' beliefs of language learning.

With some above consideration on how students' belief plays an important role in language learning especially in the context of Madurese students of IAIN Madura, it is worthy to investigate the belief of English language learners. Of course, exploring their beliefs not only impact the students but also lectures and the institution as well. For lectures, understanding 
the students' belief enable them in easily designing the classroom process, method, media, strategy for students, etc.. While the institution gain a simplicity in policymaking in line with the output of the student. Most importantly, investigating the students' belief about English language learning lead to proper English language learning instruction which later effects on the student's language achievement.

\section{Research Method}

The current study used a quantitative approach in which a survey design was primarily carried out. The primary data was gathered through administering questionnaires to reveal survey results. The questionnaires consist of two sections, namely personal data which elicits the students' name, educational and personal background as well as the various questions regarding beliefs in English language learning. The questionnaire was taken and modified from the survey form of Horwitz (1985), namely the Beliefs about Language Learning Inventory (BALLI) consisting of 34 items. The respondents of the present study were the students of English Teaching and Learning Program at State Islamic Institute of Madura (IAIN Madura), Indonesia in the second semester. A total of 144 students $(76 \%)$, 100 female $(69,4 \%)$ and 44 male $(30,6 \%)$, participated in the study.

The respondents were requested to give their level of agreement in 5-level Likert-scale; strongly agree, agree, normal, disagree, and strongly disagree administered through an online survey by using Google form. The responses have been recorded and used for further analysis by using SPSS Version 22 for windows to determine the frequency and percentage for each item.

\section{Results \& Discussion}

The BALLI (Beliefs about Language Learning Inventory) questionnaires consist of five logical areas investigated, i.e language aptitude, communication strategies, the nature in language learning, and the difficulties faced by students in language learning, as well as motivation. However, it is preceded by the data about whether students' previous knowledge by joining extra English courses. The finding revealed that $70,8 \%$ respondents have been taking English courses while $29,2 \%$ of respondents never join the English course before they enrolled in university. The data is presented in table 1 .
The question about the English course experience is necessary to investigate since it may be one of the factors influencing the students' belief about language learning later. This is relevant to the factors proposed by Abdolazeh and Nia (2014) influencing the belief of language students, such as cultural background, educational background, and experience as well as the individual differences. Besides that, the teacher's belief about language learning is also considered to exert an effect on students' belief (Abdi \& Asadi, 2015).

The first area explored through BALLI questionnaires is associated with students' language aptitude. Regarding language aptitude, ten items were delivered to seek the degree of students' agreement; strongly disagree, disagree, neutral, agree, and strongly agree. The finding revealed that among ten items associated with language aptitude, more than a half of respondents stated their agreement in several items as in item $1(59 \%)$, item $2(59 \%)$, item $4(54,9 \%)$, item 8 $(54,9 \%)$, and item $10(81,9 \%)$. Moreover, the percentage of the respondents who unsure about the items is high in several items such as item 5 $(55,6 \%)$, item $6(45,1)$, and item $9(61,1 \%)$. Interestingly, almost all items gain a number of agreements more than the number of disagreements except in item 7. Regarding this, approximately $58,3 \%$ disagree that students with high intelligence in Math are complicated to learn English. However, it does not necessarily mean that learning English is hard. The finding revealed that they believe that people competent in Math may have language aptitude which means they are competent to learn English too. Overall, the items presented in associated with language aptitude gain a high number of agreements. Besides, the high number of neutrality respondents in each item should not be ignored. Furthermore, the detailed items and the number of agreement or disagreement are presented in Table 2 following.

The result of the presents study is closely relevant with the study to Akbari \& Youran (2013). It indicated that studying English in an early age bring a positive effect. Most importantly, they also believe the existence of language ability as well as human ability to learn a foreign language and so on. Interestingly, the belief that gender difference may result in different output also gains the same perception that the disagreement is higher than the agreement. However, the number of undecided responses should be considered.

Table 1. Extra English course taken

\begin{tabular}{|l|c|c|}
\hline Joining English course & f & \% \\
\hline Yes & 102 & 70.8 \\
No & 42 & 29,2 \\
\hline
\end{tabular}


In line with the concept of human special ability for language development, the current finding proved that only 59\% of respondents agree with the notion. It is found that the percentage is quite low in compare with the study by Hapsari (2015). The statement related to personal aptitude (item 10) gained a high response of agreement. It means that they were adequately confident to concuer English. To sum up, the positive response in language aptitude can be motivation for them in English learning which the output is speaking English well.

Table 2. Language Aptitude

\begin{tabular}{|l|c|c|c|c|c|}
\hline \multicolumn{1}{|c|}{ Items } & $\begin{array}{c}\text { Strongly } \\
\text { Dissagree } \\
\mathbf{n}\end{array}$ & $\begin{array}{c}\text { Dissagree } \\
\mathbf{n}\end{array}$ & $\begin{array}{c}\text { Neutral } \\
\mathbf{n}\end{array}$ & $\begin{array}{c}\text { Agree } \\
\mathbf{n}\end{array}$ & $\begin{array}{c}\text { Strongly } \\
\text { Agree } \\
\text { N }\end{array}$ \\
\hline $\begin{array}{l}\text { Children is easier to learn English than } \\
\text { adults. }\end{array}$ & 2 & 11 & 46 & 62 & 23 \\
\hline $\begin{array}{l}\text { Some people are born with a special } \\
\text { ability which helps them learn English. }\end{array}$ & 2 & 15 & 42 & 69 & 16 \\
\hline $\begin{array}{l}\text { English structure is as same as Indone- } \\
\text { sian structure }\end{array}$ & 5 & 45 & 37 & 51 & 6 \\
\hline $\begin{array}{l}\text { It is easy for people who can speak for- } \\
\text { eign language to learn other languages }\end{array}$ & 0 & 12 & 53 & 49 & 30 \\
\hline $\begin{array}{l}\text { I have English language aptitude } \\
\text { Woman is better than man in learning } \\
\text { English }\end{array}$ & 5 & 14 & 80 & 40 & 5 \\
\hline $\begin{array}{l}\text { People who are smart in Math and Sci- } \\
\text { ence are getting difficulty in learning } \\
\text { English }\end{array}$ & 17 & 67 & 40 & 16 & 5 \\
\hline $\begin{array}{l}\text { People speaking more than one lan- } \\
\text { guage are smart }\end{array}$ & 2 & 19 & 44 & 54 & 25 \\
\hline $\begin{array}{l}\text { Indonesian people are easy to learn } \\
\text { English }\end{array}$ & 4 & 9 & 88 & 35 & 8 \\
\hline Everyone can learn English & 4 & 3 & 19 & 31 & 87 \\
\hline
\end{tabular}

The second area of students' belief about language learning is definitely about their strategy in communication. In regard to this, eight items were delivered in the questionnaire. The finding delineated that among eight items presented in this area, seven items were associated with students' belief since it reaches a high response of agreements (one item is not really high but it is the highest number of response among the level of agreement as in item 8). Based on the data presented in table 3 , majority of respondents put their agreements on item 1, 3, 4, 5, 6, 7, 8 but more than a half participant disagree about the item 2. In detail, approximately $67,4 \%$ of respondents agree that proper pronunciation is crucial in speaking English and only 10,4\% disagree while the rest of the respondents are unsure it. However, although more than half of the respondents agree that they have to speak English with good pronunciation, it does not essentially means that they are not permitted to speak unless they pronounce it perfectly. That is why about $78,5 \%$ of respondent gave their disagreement in item 2. Moreover, item 3 indicated that
$68,8 \%$ of respondents are eager to join any English conversation, but it is contrary to the fact that they $(50,7 \%)$ felt reluctant to speak. Most importantly, 91\% of respondents believe that practicing as like repeating and drilling a lot is beneficial to improve their skills. However, they (about $56,3 \%$ respondents) also argued that making mistakes will lead to fossilized mistakes as item 7 showed. Therefore, according to this belief, mistakes at the beginning of learning should be avoided to minimize any mistakes later.

When it comes to the question about their belief is associated with the nature of learning English, there are six items was given. Of those items, four items gain a high percentage of agreement. Interestingly, the majority of respondents $(86,8 \%)$ vocabulary mastery plays a crucial role in learning the language, and about 9,7\% still unsure whether they agree or not, and only a very slight number $(3,4 \%)$ denied the item. Interestingly, less than half of respondents (49\%) believe about item 4 which deals with grammar mastery, and $38,9 \%$ of respondents undecided. It is also interesting to know that about $56,9 \%$ of respond- 
Table 3. Communication Strategies

\begin{tabular}{|l|c|c|c|c|c|}
\hline \multicolumn{1}{|c|}{ Items } & $\begin{array}{c}\text { Strongly } \\
\text { Disagree } \\
\mathbf{n}\end{array}$ & $\begin{array}{c}\text { Disagree } \\
\mathbf{n}\end{array}$ & $\begin{array}{c}\text { Neutral } \\
\mathbf{n}\end{array}$ & $\begin{array}{c}\text { Agree } \\
\mathbf{n}\end{array}$ & $\begin{array}{c}\text { Strongly } \\
\text { Agree } \\
\mathbf{n}\end{array}$ \\
\hline $\begin{array}{l}\text { It's important to speak English with good } \\
\text { pronunciation }\end{array}$ & 0 & 15 & 32 & 51 & 46 \\
\hline $\begin{array}{l}\text { You are not allowed to speak English before } \\
\text { you pronuncing it well }\end{array}$ & 41 & 72 & 17 & 11 & 3 \\
\hline $\begin{array}{l}\text { If someone speaks English, I will join him/her } \\
\text { to practice my speaking skills }\end{array}$ & 0 & 3 & 42 & 63 & 36 \\
\hline $\begin{array}{l}\text { It is okay to guess the meaning of words we } \\
\text { do not know }\end{array}$ & 0 & 14 & 40 & 70 & 20 \\
\hline $\begin{array}{l}\text { Repeating and drilling is important in learn- } \\
\text { ing English }\end{array}$ & 2 & 1 & 10 & 34 & 97 \\
\hline I am shy to speak English in front of people & 5 & 20 & 46 & 63 & 10 \\
\hline $\begin{array}{l}\text { If you are allowed to make mistakes in the } \\
\text { beginning, you will frequently make mistakes } \\
\text { later }\end{array}$ & 13 & 19 & 31 & 59 & 22 \\
\hline $\begin{array}{l}\text { It is important to study English at language } \\
\text { laboratory }\end{array}$ & 8 & 24 & 53 & 39 & 20 \\
\hline
\end{tabular}

ents agree that language learning is about translating the language into the target language and only $8,3 \%$ disagree. While approximately $56,9 \%$ of respondents agree that the way they learn
English definitely differs from the way they learn other subjects and $38,2 \%$ are neutral about the item.

Table 4. The Nature of Language Learning

\begin{tabular}{|l|c|c|c|c|c|}
\hline \multicolumn{1}{|c|}{ Items } & $\begin{array}{c}\text { Strongly } \\
\text { Disagree } \\
\mathbf{n}\end{array}$ & $\begin{array}{c}\text { Disagree } \\
\mathbf{n}\end{array}$ & $\begin{array}{c}\text { Neutral } \\
\mathbf{n}\end{array}$ & $\begin{array}{c}\text { Agree } \\
\mathbf{n}\end{array}$ & $\begin{array}{c}\text { Strongly } \\
\text { Agree } \\
\text { n }\end{array}$ \\
\hline $\begin{array}{l}\text { We have to know English culture before } \\
\text { learning English }\end{array}$ & 8 & 40 & 56 & 37 & 3 \\
\hline $\begin{array}{l}\text { Learning English is better done in English } \\
\text { speaking countries }\end{array}$ & 34 & 55 & 36 & 16 & 3 \\
\hline $\begin{array}{l}\text { The most important thing in learning Eng- } \\
\text { lish is vocabulary mastery }\end{array}$ & 1 & 4 & 14 & 40 & 85 \\
\hline $\begin{array}{l}\text { The most important thing in learning Eng- } \\
\text { lish is grammar mastery }\end{array}$ & 4 & 13 & 56 & 53 & 18 \\
\hline $\begin{array}{l}\text { Learning English is different with learning } \\
\text { other subjects }\end{array}$ & 0 & 7 & 55 & 62 & 20 \\
\hline $\begin{array}{l}\text { The most important thing in learning Eng- } \\
\text { lish is translating English into Indonesian or } \\
\text { vice versa }\end{array}$ & 2 & 10 & 50 & 58 & 24 \\
\hline
\end{tabular}

Another area of students' belief explored is the belief about their difficulty in learning English. It consists of six items in which five items are voted by putting the five- level of agreements and one item is explored through different scales (less than a year, about two years, about 3-5 years and even impossible). The result shows that $31,25 \%$ students thought that some languages seem to be easier than other language and interestingly about $56,9 \%$ still undecided item 1 . It may be related to item 2 in which the respondents stated their agreement only 35,4\% which later revealed that English is included in the language easy to learn. The different result appeared in the study by Hapsari (2016). Also, regarding what skills are uncomplicated to master, either item 4 and item 5 gain the same percentage of agreement and undecided scale. In detail, about $39,6 \%$ of respondents agree that speaking is such an easy thing to accomplish than comprehending. However, nearly $39,6 \%$ of respondents stated that reading and writing is 
Another area of students' belief explored is the belief about their difficulty in learning English. It consists of six items in which five items are voted by putting the five- level of agreements and one item is explored through different scales (less than a year, about two years, about 3-5 years and even impossible). The result shows that $31,25 \%$ students thought that some languages seem to be easier than other language and interestingly about 56,9\% still undecided item 1 . It may be related to item 2 in which the respondents stated their agreement only 35,4\% which later revealed that English is included in the language easy to learn. The different result appeared in the study by Hapsari (2016). Also, regarding what skills are uncomplicated to master, either item 4 and item 5 gain the same percentage of agreement and undecided scale. In detail, about $39,6 \%$ of respondents agree that speaking is such an easy thing to accomplish than comprehending. However, nearly $39,6 \%$ of respondents stated that reading and writing is more simple than speaking and comprehending English. Interestingly, nearly $87,5 \%$ of respondents confidently believe that at the end of their learning, they will have capability in speaking English very well. It is also valuable to know that more than a half respondents believe that they will be able to speak English in a year although they spend only an hour per day in learning English, $28,5 \%$ of respondents believe that they will achieve it in two years of learning, and only a slight number of students agree that if they spend an hour a day to learn English they will master English more than three years of learning. While the rest of the respondents thought that no one could master English very well if they engage in learning only an hour a day.

Table 5. Difficulty in English Learning

\begin{tabular}{|l|c|c|c|c|c|}
\hline \multicolumn{1}{|c|}{ Items } & $\begin{array}{c}\text { Strongly } \\
\text { Disagree } \\
\mathbf{n}\end{array}$ & $\begin{array}{c}\text { Disagree } \\
\mathbf{n}\end{array}$ & $\begin{array}{c}\text { Neutral } \\
\mathbf{n}\end{array}$ & $\begin{array}{c}\text { Agree } \\
\mathbf{n}\end{array}$ & $\begin{array}{c}\text { Strongly } \\
\text { Agree } \\
\mathbf{n}\end{array}$ \\
\hline $\begin{array}{l}\text { Several languages are easier to learn than oth- } \\
\text { ers }\end{array}$ & 0 & 17 & 82 & 39 & 6 \\
\hline Learning English is easy & 1 & 15 & 77 & 44 & 7 \\
\hline $\begin{array}{l}\text { I believe that finally I can speak English very } \\
\text { well }\end{array}$ & 0 & 3 & 15 & 39 & 87 \\
\hline $\begin{array}{l}\text { Speaking English is easier than understanding } \\
\text { English }\end{array}$ & 0 & 16 & 71 & 42 & 15 \\
\hline $\begin{array}{l}\text { Reading and writing English language is easier } \\
\text { than speaking and understanding English }\end{array}$ & 3 & 17 & 67 & 39 & 18 \\
\hline
\end{tabular}

Table 6. Dificulty in English Learning (Cont)

\begin{tabular}{|l|c|c|c|c|c|}
\hline Items & $\begin{array}{c}\text { Less than } \\
\mathbf{1} \text { year } \\
\mathbf{n}\end{array}$ & $\begin{array}{c}\mathbf{1 - 2} \text { year } \\
\mathbf{n}\end{array}$ & $\begin{array}{c}3-5 \text { year } \\
\mathbf{n}\end{array}$ & $\begin{array}{c}\mathbf{5 - 1 0} \text { year } \\
\mathbf{n}\end{array}$ & $\begin{array}{c}\text { Impossible } \\
\mathbf{n}\end{array}$ \\
\hline $\begin{array}{l}\text { If someone learns English an hour a day, } \\
\text { he/she will speaks English fluently ... }\end{array}$ & 76 & 41 & 16 & 4 & 7 \\
\hline
\end{tabular}

The last area dealing with students' belief in language learning is to seek their motivation as well as their expectation during learning. Based on the finding, it is known that students have high expectations in learning English. In detail, $86,1 \%$ believe that if they are good in English, they have a number of opportunities to use it. However, only $60,4 \%$ of students believe that mastering English help them in applying for a job.

When it comes to the notion about motivation, it is interesting to know that majority of students believe about the wide opportunity of using and showing their ability in speaking English. It is a simple matter to understand that they recognized the importance of English in this era as English becomes a worldwide language spoken all over the world. However, they did not realize the role of English for better job opportunities as the percentage of agreement is only about $60 \%$. This finding is different from study by Hapsari (2015) which gained over 90\% responses. It delineated that almost all students confidently believe and feel worthy about the value of English in the job career opportunites. 
Table 7. Motivation and Expectation

\begin{tabular}{|l|c|c|c|c|c|}
\hline \multicolumn{1}{|c|}{ Items } & $\begin{array}{c}\text { Strongly } \\
\text { Disagree } \\
\mathbf{n}\end{array}$ & $\begin{array}{c}\text { Disagree } \\
\mathbf{n}\end{array}$ & $\begin{array}{c}\text { Neutral } \\
\mathbf{n}\end{array}$ & $\begin{array}{c}\text { Agree } \\
\mathbf{n}\end{array}$ & $\begin{array}{c}\text { Strongly } \\
\text { Agree } \\
\mathbf{n}\end{array}$ \\
\hline $\begin{array}{l}\text { If I speak English fluently, I will have many } \\
\text { chance to use the language }\end{array}$ & 0 & 2 & 18 & 53 & 71 \\
\hline $\begin{array}{l}\text { If I speak English fluently, I will easily get } \\
\text { jobs }\end{array}$ & 1 & 6 & 50 & 44 & 43 \\
\hline $\begin{array}{l}\text { Indonesian students think that speaking Eng- } \\
\text { lish is a crucial thing }\end{array}$ & 1 & 5 & 40 & 51 & 47 \\
\hline I want to learn English so I know the speaker & 1 & 2 & 36 & 49 & 56 \\
\hline
\end{tabular}

\section{Conclusion}

Overall, the present study show the similar pattern of students' belief in English language learning compared with previous study which explored the five general factors of belief; such as student's language aptitude, students' communication strategies, the perception of the nature of language learning, and language difficulty, their motivation and expectation in learning English as well. The finding suggest that

\section{References}

Abdi, H., \& Asadi, B. (2015). A Synopsis of Researches on Teachers' and Students' Beliefs about Language Learning. International Journal on Studies in English Language and Literature, 3(4), 104.

Abdolahzadeh, E., \& Nia, M. R. (2014). Language Learning Beliefs of Iranian Learners: Examining the Role o English Language Proficiency. Procedia - Social and Behavioral Sciences, 22-28. https://doi.org/10.1016/ j.sbspro201.03.384

Akbari, M., \& Youran, M. (2013). ASSESSING ESP LEARNERS' BELIEFS ABOUT LANGUAGE LEARNING: A SURVEY IN AN IRANIAN LOCAL CONTEXT. 3(2), 10.

Amrullah, A., Vianty, M., \& Fiftinova, F. (2018). Language Learning Beliefs of Indonesian English Education Study Program Students. https://ejournal.unsri.ac.id/index.php/ jenglish/article/download/5930/3209

Ariogul, S., Unal, D. C., \& Onursal, I. (2009). Foreign language learners' beliefs about language learning: A study on Turkish university students. Procedia - Social and Behavioral Sciences, 1(1), 1500-1506. https:// doi.org/10.1016/j.sbspro.2009.01.265

Boakye, N. (2011). Investigating students' beliefs about language learning. Per Linguam, 23 (2). https:// doi.org/10.5785/23-2-52 the importance of students' belief must gain a high concern by educational scholars since it ultimately impacted on the students achievement. Most importantly, the discussion about the factor influencing the belief can not be neglected.

Since the study is conducted in IAIN Madura, the result can not be generalized to be the finding of research in wider context.

Hapsari, P. A. (2016). The correlation between belief and students' language learning strategies at English Department of UNESA. 04, 9.

Kunt, P. S. (1996). Beliefs about language learning; The Horwitz Model. Eric Document Reproduction Service, No. ED397649). https://files.eric.ed.gov/fulltext/ ED397649.pdf

Nikitina, L., \& Furuoka, F. (2006). Re-examining Horwitz's Beliefs About Language Learning Inventory (BALLI) in the Malaysian Context. 3(2), 12.

Peralta Castro, F. M., \& Andrade-Arechiga, M. (2017). Students' Language Learning Beliefs and other Aspects that Affect Their Achievement. International Journal of Linguistics, 9(6), $74 . \quad$ https:// doi.org/10.5296/ijl.v9i6.12294

Saville-Troike, M. (2012). Introducing Second Language Acquisition (Second Edition). Cambridge Univ Press.

Zare-ee, A. (2010). Associations between university students' beliefs and their learning strategy use. Procedia - Social and Behavioral Sciences, 5, 882-886. https:// doi.org/10.1016/j.sbspro.2010.07.203 